\title{
Rural-urban differential in fertility and maternal work participation: A study in Northwestern Ethiopia
}

\author{
Chalachew Getahun Desta \\ Center for Population Studies, Addis Ababa University, \\ Addis Ababa, Ethiopia \\ e-mail: chalget@gmail.com
}

\begin{abstract}
Background: The inverse relationship between urbanization and fertility is well known in the development literature. However, whether this location difference also translates into rural-urban maternal economic outcomes differential is not well understood. Majority of past research which found inverse relationship between number of young children and maternal economic outcome failed to analyze rural and urban areas separately.

Data and methods: This paper used data from a household survey of rural and urban married women to analyze if the causal effect of fertility on maternal work participation differs between rural and urban areas.

Findings: Results show that when rural-urban location differences are considered, coefficients are negative for urban households with large number of young children and positive for those households with more adult children; whereas these coefficient signs reversed for rural households.

Conclusion: Results from the quantitative data combined with qualitative narratives suggest that large numbers of young children may not prohibit rural mothers from working.
\end{abstract}

Keywords: Maternal work participation; Amhara region of Ethiopia; lifecycle fertility; urbanization and fertility; urbanization and maternal work participation.

\section{Introduction}

The adverse consequence of rapid population growth both on national economic development and household level well-being has been widely acknowledged by the economic demographic literature. Apart from influencing academic discussions on the topic, the literature has also shaped developing countries' national population policies and programs objectives and strategies. No exception, the Ethiopian population policy and the different national development plans are also based on the premise that the rapid population growth has adverse consequence on Ethiopian development efforts (IMF, 2006; Ministry of Finance and Economic Development, 2002; 2006; 20I0; Transitional Government of Ethiopia, 1993; UNDP, 200I; UN Population Division, 2005). The consecutive five-year national development plans identify, among other things, ensuring maternal labor market participation as critical for achieving the planned development. One major strategy suggested by the plan documents to achieve this is ensuring balanced population and economic growth, for example, through reducing fertility.

In Ethiopia, fertility has been one of the highest among the developing countries, but substantial decline has begun in recent years (UN Population Division, 2017: 33). Modern contraceptive use has 4861 recently risen, for example, from II percent in 2000 (Central Statistical Agency of Ethiopia and ORC Macro, 2000) and 15 percent in 2005 (Central Statistical Agency of Ethiopia and ORC Macro, 2005) to 29 percent in 2010 (Central Statistical Agency of Ethiopia and ORC Macro, 20II). Correspondingly, total fertility rate is declining substantially though still high, for example, from 5.9 in 2000 (Central Statistical Agency of Ethiopia and ORC Macro, 2000) and 5.4 in 2005 (Central Statistical Agency of Ethiopia and ORC Macro, 2005) to 4.8 in 2010 (Central Statistical Agency of Ethiopia and ORC Macro, 20I I). Fertility is substantially lower for urban women compared to rural women. For example, for 2000, 2005 and 20II, TFR was 3.3, 2.4 and 2.6 for urban women; and 6.4, 6.0 and 5.5 for rural women (Central Statistical Agency of Ethiopia and ORC Macro, 2000, 2005, 201I). The rural-urban differential in fertility rate can be expected, but what would not be expected is the large magnitude of the difference given the low level of the urban population (about $80 \%$ of the population is employed by agriculture which is still subsistent), and lack of urban job opportunities which would discourage childbearing.

In terms of maternal work participation, the percentage of women working in productive activities is low. For example, the 2005 Ethiopian http://aps.journals.ac.za 
DHS (Central Statistical Agency of Ethiopia and ORC Macro, 2005) shows female participation rate to be $39.6 \%$ and $26.6 \%$ respectively for women in the urban and rural sub-samples by the time of the survey. The preponderance of urban women compared to rural women participating in the labor market is expected, but this difference is not comparable to the difference in their TFRs. That is, for various reasons including maternal employment and the role of other factors such as differential contraceptive use patterns, marriage rates and age at first marriage of rural and urban women, urban fertility for 2005 (the only survey which asked employment questions) was $60 \%$ lower than rural fertility, but labor market participation of urban women was only about 33\% higher than the figure for rural women. Apart from its implication for the ongoing theoretical discussion regarding maternal labor market participation effect of fertility, this low maternal labor supply amid falling fertility rate may have important implication to the achievement of the much hoped-for growth and transformation plans (GTPs), which, for example, had targeted to hit a TFR of 4.0 through accelerated structural change and urbanization.

The question of interest to the present study, therefore, is whether and the extent to which the widely acknowledged rural-urban structural difference which is assumed to have resulted in this high rural-urban fertility variation also translates into a corresponding rural-urban differential in maternal economic outcomes. Available evidence is very limited, in the sense that there is no research that analyzed data for rural and urban locations separately (existing research simply used rural-urban location dummy). For Ethiopia, a study of the relationship between fertility and maternal labor market participation even using the rural-urban location as a dummy variable is extremely limited. In this case, the first published work known to the present author is by Solomon and Kimmel (2009). As is noted above, the use of location dummy provides only overall mean difference in terms of the dependent variable (Chin, 1995). On the other hand, Desta (2017) attempted to analyze the data separately for rural and urban women, but much emphasis was given to econometric issues in discussing the results, with marginal attention to the rural-urban differential.

Therefore, the present study uses a household sample survey data from rural and urban married women with at least two live children to examine the extent to which fertility differs among samples of urban and rural women in Ethiopia, and whether and the extent to which fertility influences work participation differently for urban and rural women. In order to see the effect of sibling sex mix on the number of children as an instrumental variable, a woman should have at least two children. By doing so, the paper compares rural and urban women separately in terms of their fertility levels and work participation outcomes.

\section{Literature review and theoretical framework}

Previous research assumed fertility to vary merely by whether or not the mother was participating in paid work, without considering separate analysis for urban and rural contexts (Chin, 1995) and also without distinguishing informal activities from formal labor markets. Standard economic theories linking fertility to parental work, in general, view fertility as a response to the parents' demand for children relative to other components in the household's utility maximization decision (see e.g. Becker, 1960, 1965). In these theories, children are seen to be the result of parental choice relative to other essential household goods, all constrained by financial and time shortages in the household's utility maximization framework (Becker, 1960, 1965; Hotz and Miller, 1988). Given budget constraints in the household's utility maximization framework, parents have to make choices between labor market participation or childrearing (Becker, 1960; Hotz and Miller, 1988; Rosenzweig and Wolpin, 1980b). In this line of argument, therefore, the observed fertility is determined by variation in the opportunity cost of parental time in childcare (Becker, 1960, 1965; Hotz and Miller, 1988; Rosenzweig and Wolpin, 1980b). However, apart from failure to distinguish informal employment (e.g. self employment) from formal employment (wage and salary), existing research is constrained by two major limitations, namely, lack of analysis of fertility and maternal work participation separately for rural and urban households, and lack of dynamic analytical models.

Regarding the first issue, the inverse relationship between urbanization and fertility is well known in the socioeconomic and demographic literature since socioeconomic development and modernization creates more opportunities for women outside the domestic sphere. According to White et al (2005; 2008), in the literature, various economic, sociological, psychological and demographic explanations are offered to explain the rural-urban fertility differential, including (I) earnings forgone in raising children, (2) the employment-childrearing dilemma and resources required to raise children including urban housing, (3) ideational (beliefs and attitudes) change regarding the number and value of children and work outside the home, and (4) access to health services and modern contraceptives which influence fertility directly and/or indirectly. Whether one privileges sociological (employment-childrearing 
problem and direct childrearing costs) determined by the complex relationship of social and economic institutions in a given society, household economics (opportunity cost of childrearing) determined by economically rational choice, psychological (social networks and the diffusion of ideas), or demographic (mortality decline and the birth control) explanations, there is ample evidence to suggest that all these mechanisms operate better in urban areas. For developing countries including sub-Saharan Africa, this is due to better implementation of family planning and women's sexual reproductive health rights in urban areas often inherited from its successful implementation in Europe and women's higher social and economic status in urban compared to rural areas (Banougnin et al., 2018).

This rural-urban fertility differential has long been demonstrated for developed countries (Chin, 1995; Guo et al., 2012 and the references cited therein; Lindstorm and Woubalem, 2003; National Research Council, 2003; Sathar and Kazi, 1989; White et al., 2005;). At macro-level, there is also an inverse relationship between fertility and urbanization (defined in terms of socioeconomic development and changes in social norms and gender roles) for many developing countries, with fertility declining as development progresses (Banougnin et al., 2018; Bongaarts and Watkins 1996; Bryant, 2007; Lerch, 2017; Lindstorm and Woubalem, 2003; Mulenga et al., 2018; Sathar and Kazi, 1989; Tadesse and Headey, 20II and the references cited therein; White et al., 2005). For example, empirical evidence shows the urban fertility in Sub-Saharan Africa to be, on average, almost 30 percent lower than the rural fertility (Dudley and Pillet 1998; Fanaye Tadesse and Headey, 20ll). However, there are also studies which did not find low fertility among urban compared to rural households in sub-Saharan Africa (see. e.g. Beguy, 2009; White, 2005 and the references cited therein). This suggests that existing knowledge is not conclusive, and relatively little is known for individual developing countries, especially for sub-Saharan Africa (Beguy, 2009 and the references cited therein; Lerch, 2017; Sathar and Kazi, 1989; White et al., 2005; White et al., 2008). Most importantly, most past research used a ruralurban location dummy rather than performing separate analysis for each, which shows difference in terms of the dependent variable, but does not allow comprehensive comparison between rural and urban areas (Chin, 1995). Even as such, this offers only part of the story - rural-urban fertility differential, not rural-urban maternal employment differential.

However, it should be expected, at least theoretically, that structural difference between rural and urban areas influences the wellbeing effects of fertility to differ extensively between urban and rural households. For example, urban areas have more wage work compared to rural areas, and the nature of the urban economy is such that it is not compatible with childrearing, suggesting a fertility reducing effect. Partly for this reason, governments are often advised to accelerate urbanization and enhance the capacity of cities.

Regarding the lack of dynamic analytic models, the preponderance of static nature of models in past research is increasingly criticized since they ignore the inherently sequential nature of fertility and maternal labor supply decision making over the lifecycle (Adda, Dustmann and Stevens, 201 I; Fehr and Ujhelyiova, 2012; Francesconi, 2002; Hotz and Miller, 1988; Moffitt, 1984; Sheran, 2007). In a lifecycle framework, it is argued that since young children are more time intensive than adult children (Hotz and Miller, 1988; Fehr and Ujhelyiova, 2012; Moffitt, 1984), mothers may be less likely to work with an increasing number of young children and more likely to work when children are adults.

Lifecycle frameworks to fertility and labor supply decisions, which are seen to be dynamic and jointly determined, highlight the potential value of focusing on parents' preferred timing of childrearing and labor supply over the lifecycle (Francesconi, 2002; Hotz and Miller, 1988; McNicoll, 1984; Moffitt, 1984; Rosenzweig and Wolpin, 1980b; Sheran, 2007). In this framework, parents' fertility and labor market participation decisions reflect different timing preference. For example, couples may (I) prefer to have children early in their lifecycle and delay participation in the labor market, (2) participate in the labor market first and delay childbearing, or (3) prefer to participate in the labor market both early and latter in their lifecycle, allocating their working ages for childrearing (Cho, 2006). The framework is, therefore, considered to be a useful tool in analyzing fertility and maternal labor supply behaviors over the lifecycle (Adda, Dustmann and Stevens, 20II; Cho, 2006; Erosa, Fuster and Restuccia, 2016; Fehr and Ujhelyiova, 2012; Francesconi, 2002; Hotz and Miller, 1988; McNicoll, 1984; Moffitt, 1984; Sheran, 2007). However, while ample cross-national, macro-level empirical evidence for the age dependency hypothesis (population level) is available, the household level is empirically little explored (see e.g., Browning and Crossley, 200I; Davies, 1988; Kelley and Schmidt, 200I).

As is argued, structural difference between rural and urban areas is expected to influence the wellbeing effects of fertility to differ extensively between urban and rural households. Despite this, and, by merely modeling fertility as a function of static household choice relative to other goods and 
budget and time constraint faced by the household, past research failed to highlight whether and the extent to which the widely acknowledged rural-urban structural difference which has presumably resulted in high rural-urban fertility variation also translates into rural-urban differential in maternal socioeconomic outcomes. The present paper addresses this question.

\section{Data and methods}

Data sources

Quantitative data regarding demographic, employment and other socioeconomic characteristics over the last four months prior to the commencement of the survey were collected from a sample of 493 rural and urban married mothers with at least two children living with the household, in two different time periods. First, a sample of 254 households were interviewed in October 2010, and then with the view to increasing the earlier sample size, additional 239 sample households residing in the same place as the previous sample were interviewed in 2013. From a theoretical point of view, the time lapse may have an important effect on the outcome variables. However, given the specific context of the study region where there was no any observed demographic, socioeconomic, and institutional changes in policy and practice, the author assumed a possible effect of the time lapse to be minimal. The urban households were randomly selected from four kebeles (the smallest unit in the administrative structure of the country) out of the total of nine kebeles of the Bahir Dar City, the Amhara Regional State capital. Likewise, the rural sample households were randomly selected from two kebeles drawn from two different rural districts.

While, as is evident from the abundance of published articles, research on the link between fertility and maternal labor supply so far has typically been dominated by a quantitative approach, the use of qualitative approach to supplement and rectify weaknesses of the former is conspicuously missing. There is now an increasing consensus among scholars that the use of qualitative data within a quantitative one offers important value-adding advantages. Some of the value-adding advantages include its ability in improving household survey design, interpreting counter-intuitive or surprising findings from household surveys, explaining the reasons behind observed outcomes, probing motivations underlying observed behavior, suggesting the direction of causality, assessing the validity of quantitative results, understanding conceptual categories, and facilitating analysis of locally meaningful categories of social differentiation (Davis and Baulch, 20I I; Hulme, 2007;
Kanbur and Shaffer, 2007; Lawson, Hulme and Muwonge, 2007; Shaffer, 20I2).

This article, therefore, used qualitative observation and interview conducted with survey households, with the view to discussing results from the quantitative data analysis, and this was found especially helpful where results from the quantitative data alone were found to be inconsistent with the theoretical expectation or with most previous evidence. Six interviews and observations were made for rural women (two with women, three with children and one with a man). An observation was made as a member or members of a household engaged in an activity for the given household. In addition, government policy and program documents were used as data source. Specifically, the national population policy document of Ethiopia and other policy and program documents related to population and development such as the Sustainable Development and Poverty Reduction Program (SDPRP), Plan of Action for Sustained Development to End Poverty (PASDEP), Growth and Transformation Plan (GTP), and other relevant sectoral policies and programs were reviewed.

\section{Measurements}

The dependent variable for the present study is the mother's participation in economic activities. Most previous research defined maternal work participation as a woman's participation in that component of work which is paid (in the paid labor market), as narrowly defined in the national system of accounts (SNA). Scholars have acknowledged the problem of this narrow and restrictive definition of work, and as a consequence, an extended definition has been introduced in 1993 as an additional component (see. e. g. Antonopoulos and Hirway, 2010; Blackden \& Wodon, 2006; Colman, 1998; Francavilla et al, 20l I). The concept of maternal work in the present study is thus used in line with the extended definition to include paid or unpaid; employed or self-employed; formal or informal. The key independent variable of interest is the number of children (see discussion on the next section on how this variable was measured). In addition, a number of other demographic and socio-economic variables were also used as control variables, including average age of children (in years), sex and age (in years) of the household head, women's age at first marriage (in years), women's years of schooling, modern contraceptive use (yes $=1$; otherwise, 0 ), loan receipt (yes $=I$; otherwise, 0 ), value of household assets in terms of Ethiopian Birr - ETB (estimated by adding money value of all household assets in the then current market price), number of members in the household other than parents engaged in productive 
or non-productive work, and mean daily hours of their work. The choice of these variables is in line with most previous studies on the similar topic.

\section{Analytical strategies}

The causal effect of fertility on the economic wellbeing of children is complicated by their endogeneity. Although there are a few studies which failed to find endogeneity (Orbeta, 2005), the fact that fertility is endogenous to maternal work participation is widely acknowledged in the development literature in general and the economic demographic literature in particular, in the presence of which the use of the ordinary least squares estimator biases the effect of the number of children. While the economic demographic literature offers various approaches to account for endogeneity, one of these is the use of an instrumental variable. Several studies used different instrumental variables as a solution to this problem. These include, for example, twin first birth (Chun and Oh, 2002; Kim, Engelhardt, Prskawetz, et al., 2009; Rosenzweig and Wolpin, 1980a), abortion legislation (Bloom, Canning, Fink, et al., 2009), contraceptive choice of couples (Kim and Aassve, 2006), sibling sex composition (Angrist and Evans, 1998; Cruces and Galiani, 2007), sibling sex composition and contraception unavailability (Aassve and Arpino, 2007) and sex of the first birth (Chun and Oh, 2002; Orbeta, 2005).

The present study uses two-step instrumental variable probit (ivprobit hereafter) method, which is one of the most common instrumental variable estimators (Wooldridge, 2009). The instrumental variable used consists of sex composition of the first two siblings born to a mother (same sex $=1$; otherwise, 0 ). This instrument is chosen because sex composition of children is a random assignment and hence the sex of the siblings has no direct significant effect on maternal participation in economic activities while it impacts the number of children.

In this procedure, the first step equation uses ordinary least squares to predict the number of children as a function of the sex mix of the first and the second siblings, controlling for other covariates. Once the number of children is exogenously predicted in this way, the final equation which estimates the mother's work participation can be specified by inserting the predicted number of children as key independent variable of interest, also controlling for the same covariates in the first equation (see Appendix B). For both stages, data were analyzed first using the full sample and then separately for the urban and the rural sub-samples. In doing so, women were categorized by their children's average age groups to capture lifecycle variations in the effects.

\section{Results}

\section{Characteristics of the sample population}

The tables below offer some descriptive statistics on the demographic and economic characteristics of sample households. Table I and Table 2 provide frequency and mean values respectively for sample households on selected demographic and socioeconomic variables across the rural-urban economies. Table I shows that, compared to the rural households, urban households have a higher proportion of female-headed households, a lower proportion of households who received loan, a lower rate of maternal work participation, a lower proportion of households with more than two children, and a higher proportion of households with members other than parents who work for the household. While the higher proportion of femaleheaded households and the lower rate of maternal work participation for urban relative to rural households are consistent with previous evidence, the lower rate of loan receipt by urban compared to rural households is unexpected since urban households are expected to have better access to the service given their proximity to credit facilities and the relatively capital-intensive nature of urban jobs.

Table I. Demographic and economic characteristics of sample households (percentage)

\begin{tabular}{llll}
\hline Variables & \multicolumn{3}{l}{ Percent the event occurred } \\
\cline { 2 - 4 } & Full sample & Urban sub-sample & Rural sub-sample \\
\hline Household head is female & 19.7 & 29.3 & 10.1 \\
Participant used contraceptives & 51.5 & 74.4 & 28.6 \\
Household received loan & 43.5 & 36.2 & 51.5 \\
Participant participated in work & 47.7 & 38.8 & 56.5 \\
Members other than parents participate & 58.7 & 62.7 & 54.6 \\
in productive work & & & 63.1 \\
Members other than parents participate & 65.2 & 67.3 & 66.8 \\
in non-productive work & & & \\
First two siblings have the same sex & 62.2 & 57.5 & \\
\hline
\end{tabular}




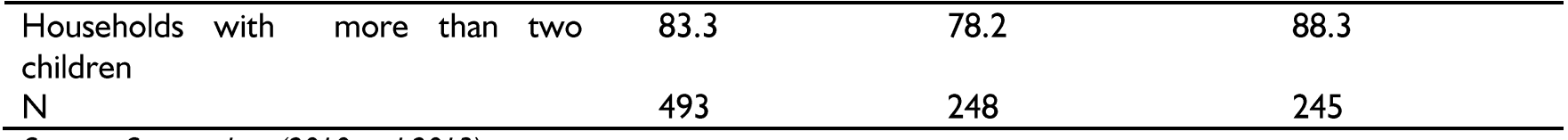

Source: Survey data (2010 and 2013).

As expected, Table 2 shows that households in the urban sub-sample have higher average age at first marriage/child bearing and years of schooling compared to households in the rural sub-sample. Table 2 also shows that household members including children for the urban sub-sample work for longer hours (perhaps due to urban children's older average ages) compared to their rural counter parts. The older average age and the fewer number of urban children is probably due to the relatively higher educational attainment of the urban women leading to the higher rates of contraceptive use (Table I) and the mother's delayed age at first marriage/child bearing (Table 2).

Table 2. Demographic and economic characteristics of sample households (means)

\begin{tabular}{|c|c|c|c|}
\hline \multirow[t]{2}{*}{ Variables } & \multicolumn{3}{|l|}{ Mean values } \\
\hline & Full sample & Urban sub-sample & $\begin{array}{l}\text { Rural sub- } \\
\text { sample }\end{array}$ \\
\hline Age of household head (years) & $\begin{array}{l}45.8659 \\
(11.9563)\end{array}$ & $\begin{array}{l}48.5623 \\
(12.3264)\end{array}$ & $\begin{array}{l}41.9875 \\
(9.8497)\end{array}$ \\
\hline Average age of participant's children (years) & $\begin{array}{l}13.7410 \\
(8.0197)\end{array}$ & $\begin{array}{l}17.00 \mid 4 \\
(8.997 \mid)\end{array}$ & $\begin{array}{l}11.0108 \\
(5.8945)\end{array}$ \\
\hline Participant's age at first marriage (years) & $\begin{array}{l}15.7618 \\
(3.61805)\end{array}$ & $\begin{array}{l}16.996 \mid \\
(3.8599 \mid)\end{array}$ & $\begin{array}{l}14.5276 \\
(2.88352)\end{array}$ \\
\hline Participant's age at bearing first child (years) & $\begin{array}{l}17.3415 \\
(3.0002)\end{array}$ & $\begin{array}{l}18.7034 \\
(3.5 \mid 42)\end{array}$ & $\begin{array}{l}16.9856 \\
(2.4315)\end{array}$ \\
\hline Participant's years of schooling ( 0 if no schooling) & $\begin{array}{l}3.7981 \\
(4.8475)\end{array}$ & $\begin{array}{l}5.9107 \\
(4.8910)\end{array}$ & $\begin{array}{l}2.0098 \\
(2.7458)\end{array}$ \\
\hline Value of household assets (ETB)* & $\begin{array}{l}13904.0397 \\
(15047.4125)\end{array}$ & $\begin{array}{l}15152.3254 \\
(16049.1152)\end{array}$ & $\begin{array}{l}11001.75 \\
(15012.3)\end{array}$ \\
\hline $\begin{array}{l}\text { Mean hours of work per day by household } \\
\text { members (excluding parents) }\end{array}$ & $\begin{array}{l}3.02 \\
(0.21)\end{array}$ & $\begin{array}{l}4.00 \\
(0.34)\end{array}$ & $\begin{array}{l}2.1 \\
(0.21)\end{array}$ \\
\hline $\mathrm{N}$ & 493 & 248 & 245 \\
\hline
\end{tabular}

Note: Standard deviations are reported in parenthesis. Source: Survey data (2010 and 2013).

* I USD $=16.636$ ETB on 31 December 2010, and 19.1218 ETB on 31 December 2013.

Number of children and maternal employment status

Tables 3 and 4 below describe the rural-urban differential in the number of children and maternal rate of work participation in relation to the number of children. As expected, Table 3 shows a statistically significant difference in the number of children for women between urban and rural sub-samples. This result is in line with the available empirical evidence.

Table 3. Rural-urban variation in the number of children (mean difference)

\begin{tabular}{clccc}
$\begin{array}{c}\text { Full sample } \\
(\mathrm{N}=493)\end{array}$ & $\begin{array}{c}\text { Urban sub-sample } \\
(\mathrm{N}=248)\end{array}$ & $\begin{array}{c}\text { Rural sub-sample } \\
(\mathrm{N}=245)\end{array}$ & $\begin{array}{c}\text { Rural-urban } \\
\text { differential* }\end{array}$ & $\begin{array}{c}\text { Sig. (2-tailed) } \\
\text { for } \\
\text { differential }\end{array}$ \\
\hline 4.8992 & 4.4597 & 5.3387 & 0.8790 & 0.003 \\
$(2.321)$ & $(2.1276)$ & $(2.4291)$ & $(.2899)$ & \\
\hline
\end{tabular}

Note: Standard deviations are reported in parenthesis (standard error differences are reported for the rural-urban differential). Source: Survey data (2010 and 2013).

Table 4 depicts that the work participation rate of the mother during the specified period differ for the urban and the rural sub-samples. It shows that mothers who participated in productive work increase with an increase in the number of children for the rural sub-sample, and, generally, for the full http://aps.journals.ac.za sample. The situation is less consistent for the urban sub-sample. However, the table clearly shows that the mother's work participation is relatively smaller for the urban sub-sample both on average and for each age group. 
Table 4. Number of children and percentage of women who participated in productive work prior to the survey

\begin{tabular}{|c|c|c|c|c|c|c|}
\hline \multirow{2}{*}{$\begin{array}{l}\text { No. of } \\
\text { children }\end{array}$} & \multicolumn{2}{|c|}{ Full sample } & \multicolumn{2}{|r|}{ Urban } & \multicolumn{2}{|r|}{ Rural } \\
\hline & $\mathrm{N}$ & $\begin{array}{l}\% \text { women } \\
\text { working }\end{array}$ & $\mathrm{N}$ & $\begin{array}{l}\text { \% women } \\
\text { working }\end{array}$ & $\mathrm{N}$ & $\%$ women working \\
\hline 2 & 82 & 34.3 & 53 & 31.2 & 29 & 42.6 \\
\hline $3-4$ & 148 & 46.8 & 86 & 55.1 & 62 & 37.9 \\
\hline $5-6$ & 149 & 42.1 & 63 & 21.8 & 86 & 55.1 \\
\hline $7-8$ & 76 & 60.7 & 32 & 36.2 & 44 & 77.5 \\
\hline $9-10$ & 30 & 58.2 & 14 & 27.3 & 16 & 86.2 \\
\hline$>=11$ & 8 & 100 & --- & & 8 & 100 \\
\hline Total & 493 & 47.7 & 248 & 38.8 & 245 & 56.5 \\
\hline
\end{tabular}

Source: Survey data (2010 and 2013).

Having described the characteristics of the study population and the rural-urban variation in the number of children and maternal work participation, we now turn on to analyzing the effect of the number of children on the maternal work participation, using the two step instrumental variable estimator of the ivprobit model. Table 5 shows parameter estimates for the ivprobit model (and exogenous probit model). Note that this study does not intend to discuss coefficients from control variables (see the Appendix for coefficients from control covariates).

The table consists of three panels. Each panel compares results for the rural and urban locations. The first panel shows results for all households that differ only in their rural-urban location. The second and the third panels show results for households that differ by the age group of their children, in addition. For the first panel, first, the ivprobit estimate has all positive coefficients for both the rural and urban locations, suggesting that an increase in the number of children is associated with an increase in the probability of the mother's work participation for the households, despite the lack of statistical significance for the ivprobit coefficients. While the lack of statistical significance for the ivprobit coefficients as opposed to those using the exogenous model is consistent also with several other previous research, the lack of difference in coefficient signs by ruralurban location is surprising because the difference in the employment structure between the rural and the urban economies is expected to respond to the effect of the number of children differently for the rural and the urban locations. However, this difference becomes fairly apparent once the lifecycle effect is considered by categorizing households according to age groups of their children (the last two panels of Table 5).

The second panel of the table shows results for mothers with children of ages less than ten years. The third panel shows results for those mothers with children of ages ten years or older. For the urban sub-sample, the ivprobit coefficient is negative for the second panel, suggesting, as expected, that large number of young children decreases the probability of the mother's work participation, although it is not statistically significant. In the third panel, the ivprobit coefficient is positive and statistically significant at $p=$ 0.084 , suggesting that for urban mothers with more adult children, the negative effect of the number of children disappears and contributes positively. For the rural sub-sample, the ivprobit coefficient is positive and statistically significant for the second panel at $p=0.092$, suggesting that large number of young children increase the mother's probability of work participation. By contrast, for the third panel the ivprobit coefficient is negative, suggesting a reversal in the positive effect of the number of children, although it is not statistically significant.

Table 5. Parameter estimates for maternal work participation by the number of children (with other variables controlled)

\begin{tabular}{|c|c|c|c|c|c|c|c|}
\hline \multirow{2}{*}{$\begin{array}{c}\text { Group of } \\
\text { households }\end{array}$} & \multirow[t]{2}{*}{ Model } & \multicolumn{2}{|c|}{ Full sample } & \multicolumn{2}{|c|}{ Urban sub-sample } & \multicolumn{2}{|c|}{ Rural sub-sample } \\
\hline & & Coef. & $p>z$ & Coef. & $p>z$ & Coef. & $p>z$ \\
\hline & $\begin{array}{l}\text { Exogenous } \\
\text { probit }\end{array}$ & $\begin{array}{l}.0918 \\
(.0321)\end{array}$ & 0.070 & $\begin{array}{l}-.2156 \\
(.0452)\end{array}$ & 0.061 & $\begin{array}{l}.1568 \\
(.0425)\end{array}$ & 0.004 \\
\hline All households & ivprobit & $\begin{array}{l}.1671 \\
(.2031)\end{array}$ & 0.418 & $\begin{array}{l}.0304 \\
(.1549)\end{array}$ & 0.315 & $\begin{array}{l}.8412 \\
(.1456)\end{array}$ & 0.113 \\
\hline & $\mathrm{N}$ & 493 & & 248 & & 245 & \\
\hline
\end{tabular}




\begin{tabular}{|c|c|c|c|c|c|c|c|}
\hline $\begin{array}{l}\text { Households with } \\
\text { children of ages }\end{array}$ & $\begin{array}{l}\text { Exogenous } \\
\text { probit }\end{array}$ & $\begin{array}{l}.1903 \\
(.1102)\end{array}$ & 0.021 & $\begin{array}{l}.1843 \\
(.3201)\end{array}$ & 0.321 & $\begin{array}{l}.1497 \\
(.1222)\end{array}$ & 0.107 \\
\hline$<10$ years & ivprobit & $\begin{array}{l}.3349 \\
(.9742)\end{array}$ & 0.420 & $\begin{array}{l}-.0989 \\
(1.7025)\end{array}$ & 0.498 & $\begin{array}{l}.7008 \\
(.5079)\end{array}$ & 0.092 \\
\hline & $N$ & 217 & & 99 & & 118 & \\
\hline $\begin{array}{l}\text { Households with } \\
\text { children of ages }\end{array}$ & $\begin{array}{l}\text { Exogenous } \\
\text { probit }\end{array}$ & $\begin{array}{l}.9963 \\
(.1515)\end{array}$ & 0.088 & $\begin{array}{l}-.0845 \\
(.0852)\end{array}$ & $0.54 I$ & $\begin{array}{l}.2111 \\
(.0981)\end{array}$ & 0.026 \\
\hline$>=10$ years & ivprobit & $\begin{array}{l}.0711 \\
(.1845) \\
276\end{array}$ & 0.476 & $\begin{array}{l}.1252 \\
(.3602) \\
49\end{array}$ & 0.084 & $\begin{array}{l}-.9932 \\
(6.961) \\
127\end{array}$ & 0.566 \\
\hline
\end{tabular}

Note: Standard errors are reported in parenthesis. Source: Survey data (2010 and 2013).

\section{Discussion}

The negative ivprobit coefficient on the probability of maternal work participation effect of young children for the urban mother in the second panel (despite its being statistically insignificant) and the positive and statistically significant ivprobit coefficient in the third panel is consistent with most previous evidence, although most such research is based on rural-urban dummy instead of running separate analysis for rural and urban mothers (see e.g., Angrist and Evans, 1998; Cáceres-Delpiano, 2008; Chun and Oh, 2002; Cruces and Galiani, 2007; Dupta and Dubey, 2003; Kim and Aassve, 2006; Orbeta, 2005; and references therein). This result is also consistent with previous lifecycle evidences. For example, Hotz and Miller (1988) found that children tended to have negative effects during their early ages but not during their adult ages, and that the intensity of time the mother spent tending her children markedly declined as children grew up. Similarly, Assaad and Zouari (2003) for urban Morocco found that the presence of schoolage children significantly reduced the participation of women from all types of paid work.

The positive and statistically significant ivprobit coefficient for the rural sub-sample in the second panel, and the negative though statistically insignificant ivprobit coefficient in the third panel, nevertheless, are inconsistent with the theoretical prediction that holds that, other factors held constant, the mother's probability of work participation decreases with an increase in the number of young children and increases when children become more adult. However, consistent with this result, using data from the 2000 Ethiopian DHS and instrumenting the number of children with the husband's desire for children, Solomon and Kimmel (2009) found positive (but statistically insignificant) maternal labor supply effect of children. In this connection, Angrist and Evans (1998:463) also cite a review that found that fertility either has no effect on maternal labor supply, or it has a positive effect when endogeneity is considered. In the context of fertility and poverty, Mberu et.al's (2016) review of past research also shows positive relationship between fertility and poverty for many developing countries and negative relationships for some very poor countries.

In the present study, it is argued that, despite the lack of statistical significance for many of the ivprobit coeffcients, the quantitative results' inconsistency with theory and most previous research for the rural households is rather due to the rural-urban difference in the employment structure and the effect of the household's lifecycle. Context-specific literature review and qualitative data seem to be revealing in this particular case.

First, the prevalence of household enterprises and traditional nature of farming in rural areas of poor economies including Ethiopia means that more rural women have to work longer compared to urban women (see e.g., Arbache, Kolev and Filipiak, 20I0). In Ethiopia, farm plots are fragmented, farming is done manually, and productivity is low. Households have to invest a lot of manual labor per unit area, and, as such, it would be likely for women to work in the farms especially when there are other children to look after very young children at home. In such circumstances, children may not be considered that much prohibitive to the mother's work given the nature of the economy and the mother's need to work for the family, despite the adverse health implications that this is likely to have on the young children. There is ample evidence on this from maternal work and child care literature (e.g., Samman, Presler-Marshall and Jones, 2016 and the references therein).

Second, work conditions are more flexible for rural economies than for urban economies (Kim and Aassve, 2006). Farms are not too far from the house and the mother can flexibly use her time taking care of her child at home and working in the nearby farm plot. Even where farm plots are away from home, the mother can still manage to work. It is common, in Ethiopia for example, to see mothers doing the farming activities holding children on their backs or placing them in a tree shade beside the farm with another young child to look after the youngest child. 
This has also been well confirmed by information from qualitative observation and interview with some sample households.

A twenty-eight year old woman was holding her five-month daughter on her back when I met her cutting fodder from her maize farm. Her responses to questions I raised in the interview illustrates the argument above:

My husband is sowing shimbra [a local name for chickpeas] in another farm plot. My daughter is sleeping now on my back, but she will begin crying eventually as she feels hot in the sun. Sometimes, she develops fever at night. I know this is bad for her, but I have to do this because there is no option. My younger sister, whom I brought to help with the household activities following my delivery is there working in the farm with my husband removing the weeds. I could have brought my other two children with me here to look after my daughter in the tree shade, but they are in the house watching for sito [some raw food stuffs such as grains, cereals, etc. put to dry in the sun before further processing] from bird pests.

Third, young children in many cases contribute to the family labor by taking care of the domestic chores, which is well documented in the literature (Aghajanian, 1979; Boserup, 1985; Caldwell and Caldwell, 1987; Cho, 2006). According to Cho (2006), children contribute to household economy by replacing the mother's activity at home. Boserup (1985) and Caldwell and Caldwell (1987) argue that in addition to their labor input, children in subSaharan Africa demand little child care, allowing the mother to spend her time on work. In the case of Ethiopia, Solomon and Kimmel (2009) also note that young children often contribute to domestic chores which allows the mother to work away from home. They also note that Ethiopian mothers are unlikely to leave their jobs in the face of high unemployment and underemployment rates in the country. The quantitative data for the present study shows that members engaged in housework for the household increased the work participation rate of the mother (see Appendix A). This result has also been well confirmed by qualitative observation and interview with children and parents. The qualitative data revealed that children were able to work for the household both as non-school children, pre-school children and school children. Some school-age children had their parents refused to send them to school, and so work for them; some children were too young for schooling, but can do some kind of work for their family (as in the young children's taking care of the sito in the house in the quotation above), and some others use their non-school hours for family work, such as the mornings, evenings, and the other half (non-school shift) of the school day. In addition, many rural parents detain their children from school for several days, especially when there is a sign of untimely rain coming during periods of crop harvest.

Equally inconsistent with theory and most available evidence, despite the lack of statistical significance, is the more adult children's negative contribution to rural maternal work participation. In Ethiopia, it is often common to see older mothers working only a few hours a day or absenting themselves from farm work at all and staying home doing domestic chores compared to younger mothers. Results from the quantitative data show that, contrary to the positive maternal work participation effect of members engaged in housework, members engaged in productive work decreased the mother's work participation. It can be argued that this is probably the result of work substitutability between the mother and other members of the household including children (especially of adult ones). This appears to have been also reinforced by other context-specific circumstances such as land tenure and the subsistence nature of farming coupled with poverty. In Ethiopia, land is owned by the state since 1974 and farmers have utilization rights of the land they have held. There were periodic land redistribution schemes during the Dergue government (19741991). The existing government had also redistributed land in 1995/96 and has certified the farmers as a security to their land utilization right. There has not been any redistribution carried out thereafter. As a result, male children were implicitly obliged to continue to work on parents' land, mainly as sharecroppers, even having been married and having own family. Their marriage increases the household's labor force thus further encouraging the mother to stay home doing the household chores. Even when married children might in some cases work on their own farm, or migrate to cities where they engage in non-farm activities, they might have to spend some days helping on their poor parents' farms, or hiring some daily labor for them. The rural to urban migration effect of restrictions in youth access to land is well documented in Bezu and Holden (Bezu and Holden, 20I4). On the other hand, some better-off parents were able to hire daily labor by their own.

Evidence from the qualitative interview and observation is much more revealing. A forty-one year old woman having five live children out of six demonstrates this as follows:

.... My eldest son has now passed 24 and has obtained two children. My second child is male and my third child is female. Both are married and 
have one child each. My fifth child [the fourth was dead] is male and is a grade II student living far away from us, and my youngest child is female and is a grade 8 student. ... Despite our land's being not big enough, we gave a small plot to our eldest son, but the kebele [a local equivalent for village administration] said he will not be given ownership certificate since no more land sub-division is allowed. As to our second son, we convinced him to farm with us and share the harvest. Our son and his wife and my husband as well took care of the farm work, and I stayed home preparing food for them and doing other activities. Meanwhile, our son left for ketema [a local equivalent for urban area] and now works there as gimbegna [a local equivalent for construction worker]. Initially, his wife was still with us and was of great assistance working in the farms. Later on, however, he took her (along with her child) and I had to come back to farm work. This was difficult for me and my husband. We have grown these children, and are now getting old that we are not as strong to work in the farms as before. We also do not have money to pay for yeqen-serategna [a local equivalent for daily wage laborer] as our rich neighbors do. But, Egziabher yimesgen [a local equivalent for thanks to God], our eldest son agreed to work with us instead since the plot of land we gave him was too small, and so we merged the farm plots. Once again, my activity was confined to housework. Occasionally, especially during periods of peak farm activity, our son from ketema also sends us money to hire yeqen-serategna.

If the situation for women in the rural sub-sample can be explained in this way, what can explain the case for women in the urban sub-sample (mothers of children of ages less than 10 years) whose coefficient is negative but not statistically significant? The forgoing discussion regarding the theoretically inconsistent results of maternal work participation effect of children in rural areas contrasted the traditional and subsistent nature of the rural economy against the urban modern economy, the latter often characterized to be so by the theoretical literature. However, in practice, much of the Ethiopian urban labor market is informal, and so can be compared (rather than contrasted) to its rural counterpart. The coefficient is negative because ( $I$ ) young children can deter some of the women who have to work for wage (public, private), and (2) scarce urban job opportunities and low wages coupled with the high rural-urban migration may confine women to childcare and domestic chores. While informal activity is often mentioned as the solution because of the alleged ease with entry (e.g., low start-up capital, no license requirements, low skills, flexible working premises, and so forth) (Desta, 20l8), starting own business may be practically difficult for very poor urban women who do not have the startup capital even as it is low. The low proportion of urban women working in the data may help explain this. On the other hand, the coefficient is statistically insignificant perhaps because of the informal, childfriendly nature of most urban jobs, which may not necessitate hiring of childcare givers. Even when a woman considers to hire childcare giver, this is not easy since it brings her in stiff competition with the informal employers in other activities, such as construction, which rely heavily on unskilled labor (Desta, 2018). The wage offered by such employers often outbids the price poor urban households can offer.

\section{Conclusion}

The rural-urban fertility differential is widely acknowledged in the socioeconomic and demographic literature. However, very little is known whether this fertility differential also translates to a corresponding rural-urban differential in maternal work participation. This paper used data from a household sample survey of women with at least two live children to examine the extent to which fertility differs among samples of urban and rural women in Ethiopian, and whether and the extent to which fertility influences work participation differently for urban and rural women.

Results show that, when all households are considered, children seem to have positive effects on the probability of the mother's work. However, when household lifecycle differences are considered, coefficients are negative (but statistically insignificant) for households with large number of young children and positive for those households with more adult children for the urban sub-sample. Whereas for the rural sub-sample, coefficients signs are reversed roughly suggesting inconsistency with the theory and previous research evidence for other countries.

The lack of statistical significance of some of the results in the present paper, suggests the difficulty of drawing a valid conclusion from the quantitative results alone in this particular case, in which analysis is rather based on a small sample. However, results from the quantitative data combined with qualitative narratives suggest that large numbers of young children may not prohibit rural mothers from working, but they are also not that prohibitive of urban mothers work participation. The qualitative data and the reviews of context-relevant literature appear to have offered possible explanations for these results, which, from the quantitative literature point of view, seem inconsistent. 


\section{References}

Aassve, A. and Arpino B. 2007. "Estimation of causal effects of fertility on economic wellbeing: evidence from rural Vietnam". ISER Working Paper No. 24. University of Essex and University of Florence.

Adda, J. Dustmann. C and Stevens, K. 20II. "The career costs of children". IZA Discussion paper No. 620I: Institute for the Study of Labor.

Aghajanian, A. 1979. "Family economy and economic contribution of children in Iran: An overview". Journal of South Asian and Middle Eastern Studies 35, (I): 21-30.

Angrist, J.D. and Evans, W. 1998. "Children and their parents' labor supply: Evidence from exogenous variation in family size". The American Economic Review 88, (3): 450-477.

Antonopoulos, R. and Hirway, I. 20I0. "Unpaid work and the economy: Gender, time use and poverty". In Antonopoulos, R. and Hirway, I. (eds.) Unpaid work and the economy: Gender, time use and poverty in the Global South, UK: Palgrave Macmillan.

https://link.springer.com/content/pdf/ I 0. I057/978 0230250550_I.pdf

Arbache, J.S., Kolev, A. and Filipiak, E. 20I0. "Why study gender disparities in Africa's labor market?" In Arbache, J.S., Kolev, A. and Filipiak, E. (eds.). Gender disparities in Africa's labor market. Washington D. C.: The World Bank. DOI: I0.I596/978-0-82। 3-8066-6

Assaad, R. and Zouari, S. 2003. "Estimating the impact of marriage and fertility on the female labor force participation when decisions are interrelated: Evidence from urban Morocco". Topics in Middle Eastern and North African Economies, Vol. 5. Middle East Economic Association and Loyola University Chicago.

Banougnin, B.H., Adekunle, A.O., Oladokun, A. and Sanni, M.A. 2018. "Impact of internal migration on fertility in Cotonou, Benin Republic". African Population Studies 32, (2): 4305-43I 8.

Becker, G.S. 1965. "A Theory of the allocation of time". The Economic Journal 75, (299): 493-5I 7.

Becker, G.S. 1960. "An economic analysis of fertility". In Universities-National Bureau (eds.). Demographic and economic change in developed countries. Columbia: Columbia University Press.

Beguy, D. 2009. "The impact of female employment on fertility in Dakar (Senegal) and Lomé (Togo)". Demographic Research 20, (7): 97-128. DOI: 10.4054/DemRes.2009.20.7

Bezu, S. and Holden, S. 2014. "Are rural youth in Ethiopia abandoning agriculture?" World Development, 64: 259-272. http://dx.doi.org//0.1016/j.worlddev.2014.06.013
Blackden, C.M and Wodon, Q. 2006. "Gender, time use, and poverty in sub Saharan Africa". World Bank Working Paper No. 73, Washington, D.C. DOI: |0.1596/978-0-82 |3-656|-8.

Bloom, D. Canning, D. Fink, G. and Finlay, J. 2009. "Fertility, female labor force participation, and the demographic dividend". Journal of Economic Growth I4, (2): 79-101.

DOI 10.1007/s 10887-009-9039-9

Bongaarts, J. and Watkins, S.C. 1996. "Social interactions and contemporary fertility transitions". Population and Development Review 22, (4): 639-682.

Boserup, E. 1985. "Economic and demographic interrelationships in sub-Saharan Africa". Population and Development Review II, (3): 383397.

Browning, M. and Crossley, T. 200I. "The life-cycle model of consumption and saving". Journal of Economic Perspectives 15, (3): 3-22. DOI: 10.1257/jep. I5.3.3

Bryant, J. 2007. "Theories of fertility decline and the evidence from development indicators". Population and Development Review 33, (I): 101127.

Cáceres-Delpiano, J. 2008. "Keeping the best for last: Impact of fertility on mother's employment: Evidence from developing countries". Working paper 08-68 No. 32. Universidad Carlos De Madrid.

Caldwell, J. and Caldwell, P. 1987. "The cultural context of high fertility in sub Saharan Africa". Population and Development Review 13, (3): 409435.

Central Statistical Agency of Ethiopia and ORC Macro (2000). The Ethiopian Demographic Health Survey. Addis Ababa.

Central Statistical Agency of Ethiopia and ORC Macro (2005). The Ethiopian Demographic Health Survey. Addis Ababa.

Central Statistical Agency of Ethiopia and ORC Macro (20I I). Ethiopia Demographic and Health Survey 201 I: Preliminary report. Addis Ababa.

Chin, S.H. 1995. "The determinants and patterns of married women's labor force participation in Korea". Korea Journal of Population and Development 24, (I): 95-129.

Cho, Y. 2006. "An analysis of women's fertility and labor supply: implications for family policies. Paper presented at International Conference on Declining Fertility in East and Southeast Asian Countries, December I4-I5, Tokyo.

Chun, H. and Oh, J. 2002. "An instrumental variable estimate of the effect of fertility on the labor force participation of married women". Applied 
Economics Letters, 9: 63I-634. DOI: I0.1080/I3504850I I0I I 7850

Colman, R. 1998. "The economic value of unpaid housework and childcare in Nova Scotia, GPI Atlantic, Halifax, Nova Scotia. http://www.gpiatlantic.org/publications/summaries /houseworksumm.pdf

Cruces, G. and Galiani, S. 2007. "Fertility and female labor supply in Latin America: New causal evidence". Labour Economics 14, (3): 565-573. https://doi.org/10.1016/j.labeco.2005.10.006

Davies, J. 1988. "Family size, household production, and life cycle saving". Annales D'economie Et De Statistique, 9:

$|4|-\mid 65$. DOI: 10.2307/20075685

Davis, P. and Baulch, B. 20II. "Parallel realities: Exploring poverty dynamics using mixed methods in rural Bangladesh". The Journal of Development Studies $\quad 47, \quad$ (I): $\quad|| 8-\mid 42$. https://doi.org// 0.1080/00220388.2010.492860

Desta, C.G. 2017. "Do young children prohibit mothers from working? A study in the Amhara Region, Ethiopia". International Journal of Population Studies 3, (2): 29-42.

Desta, C.G. 2018. "The urban informal economy in Ethiopia: Theory and empirical evidence". Eastern Africa Social Science Research Review 34, (I): 3763.

Dudley, K. and Pillet, B. 1998. "Fertility levels, trends and differentials in sub-Saharan Africa in the 1980s and 1990s". Studies in Family Planning, I-22.

Dupta, N.D. and Dubey, A. 2003. "Poverty and fertility: An instrumental variables analysis on Indian micro data". Working paper series II. Department of Economics, Aarhus School of Business.

Erosa, A. Fuster, L. and Restuccia, D. 2016. "A quantitative theory of the gender gap in wages". European Economic Review, 85: 165-187. http://dx.doi.org/10.1016/j.euroecorev.2015.12.01 4

Fehr, H. and Ujhelyiova. 20I2. "Fertility, female labor supply, and family policy". German Economic Review |4, (2): 138-165.

Francavilla, F., Giannelli, G. Claudia, G.G. and Socha, M.W. 20II. "Use of time and value of unpaid family care work: A comparison between Italy and Poland". IZA Discussion Paper No. 577I, Institute for the Study of Labor: Bonn Germany.

Francesconi, M. 2002. "A joint dynamic model of fertility and work of married women". Journal of Labor Economics 20, (2): 336-380.

Guo, Z., Wu, Z., Christoph, M.S. and Shuzhuo, L. 2012. "The effect of urbanization on China's fertility". Population Research and Policy Review 3I, (3): 4I 7-434.
Hailemariam, A. Alayu, S. and Teller, C. 20II. "The national population policy (NPP) of Ethiopia: Achievements, challenges and lessons learned, 1993-2010". In Teller, C and Hailemariam, A. (eds.). The demographic transition and development in Africa: The unique case of Ethiopia. London, New York: Springer. DOI 10.1007/978-90-48|-89/8-2

Hotz, V.J. and Miller, R.A. 1988. "An empirical analysis of life cycle fertility and female labor supply". Econometrica 56, (I): 19-I I8.

Hulme, D. 2007. "Integrating quantitative and qualitative research for country case studies of development". GPRG-WPS No. 063. Global Poverty Research Group.

IMF (2006). The Federal Democratic Republic of Ethiopia: Poverty Reduction Strategy Paper 2003/04 Annual Progress Report. Country report No. 06/27. Washington D. C.

Kanbur, R and Shaffer, P. 2007. "Epistemology, normative theory and poverty analysis: Implications for Q-Squared in practice". World Development $\quad 35, \quad$ (2): $\quad$ I83-196. doi:10.1016/j.worlddev.2005.10.016

Kelley, A. and Schmidt, R. 200I. "Economic and demographic change: A synthesis of models, findings and perspectives". In Birdsall, Kelley and Sinding (eds.). Population Matters. New York: Oxford University Press. DOI: 10.1093/0199244073.001.0001

Kim, J. and Aassve, A. 2006. "Fertility and its consequence on family labor supply". IZA Discussion paper series 2162. Vienna Institute of Demography \& IZA Bonn \& University of Essex.

Kim, J., Engelhardt, H., Prskawetz, A. and Aassve, A. 2009. "Does fertility decrease household consumption? An analysis of poverty dynamics and fertility in Indonesia". Demographic Research, 20(26):

623-656.

DOI: 10.4054/DemRes.2009.20.26

Lawson, D., Hulme, D. and Muwonge, J. 2007. "Methodological issues associated with combining quantitative and qualitative approaches to understanding poverty dynamics: Evidence from Uganda". GPRG-WPS No. 077. Global Poverty Research Group.

Lerch, M. 2017. "Urban and rural fertility transitions in the developing world: a cohort perspective". MPIDR Working Paper WP 20 I7-0I I. Max Planck Institute for Demographic Research.

Lindstorm, D.P. and Woubalem, Z. 2003. "The demographic components of fertility decline in Addis Ababa, Ethiopia: A decomposition analysis". GENUS LIX, (3-4):, I 47-I 58.

Mberu, B.U., Ciera, J.M., Elungata, P. and Ezeh, A.C. 2016. "Fertility and household economic 
outcomes among poor households in Nairobi informal settlements, Kenya". African Population Studies 30, (3): 3036-3046.

McNicoll, J. 1984. "Consequences of rapid population growth: An overview and assessment". Population and Development Review 10, (2): 177-233.

Ministry of Finance and Economic Development (2002). Ethiopia: Sustainable Development and Poverty Reduction Program. Addis Ababa. http://planipolis.iiep.unesco.org/sites/planipolis/file s/ressources/ethiopia_prsp.pdf

Ministry of Finance and Economic Development (2006). Ethiopia: Building on Progress: A Plan for Accelerated and Sustained Development to End Poverty (2005/06-2009/10). Volume I. Addis Ababa.

https://extranet.who.int/nutrition/gina/sites/default /files/ETH\%202005\%20Plan\%20for\%20Accelera ted\%20and\%20Sustained\%20Development $\% 20 \mathrm{t}$ ०\%20End\%20Poverty\%20\%28PASDEP\%29.pdf

Ministry of Finance and Economic Development (2010). Growth and Transformation Plan (20I0/II- 20I4/I5). Volume I. Addis Ababa. http://et.one.un.org/content/dam/unct/ethiopia/do cs/GTP\%20English\%20Voll\%20(I).pdf

Moffitt, R. 1984. "Profiles of fertility, labor supply and wages of married women: A complete life-cycle model". The Review of Economic Studies 5I, (2): 263-278. https://doi.org// 0.2307/229769I

Mulenga, J., Mulenga, M.C., Bwalya, B.B. and Ngongola-Reinke, C. 2018. "Too young to be a wife! Analysis of the factors influencing child marriages and its influence on the preferred number of children among women in Zambia". African Population Studies 32, (2, Oct./Nov. 2018): 4319-433।.

National Research Council (2003). "Cities transformed: Demograpic change and its implication in the developing world". Washington DC: The National Academic Press.

Orbeta, A. 2005. "Children and the labor force participation and earnings of parents in the Philippines". Philippine Journal of Development 32, (I): 19-52.

Ringheim, K., Teller, C. and Sines, E. 2009. Ethiopia at a crossroads: Demography, gender, and development. Policy brief. Washington D. C: Population Reference Bureau.

Rosenzweig, M.R. and Wolpin, K.I. 1980a. "Testing the Quantity-Quality Fertility Model: The use of

White, M.J., Muhidin, S., Andrzejewski, C., Tagoe, E., Knight, R. and Reed, H. 2008. "Urbanization and fertility: An event history analysis for coastal Ghana". Demography 45, (4): 803-8I6.

White, M.J., Tagoe, E., Stiff, C., Adazu, K. and Smith, D.J. 2005. "Urbanization and the fertility transition twins as a natural experiment". Econometrica 48, (I): 227-240.

Edition. Mason OH USA: South-Western SENGAGE Learning.

Rosenzweig, M.R. and Wolpin, K.I. 1980b. "Lifecycle labor supply and fertility: Causal inferences from household models". Journal of Political Economy 88, (2): 328-348.

Samman, E., Presler-Marshall, E. and Jones, N. 2016. "Women's work: Mothers, children and the global childcare crisis". ODI Report. London: Overseas Development Institute.

Sathar, Z.A. and Kazi, S. 1989. "Female employment and fertility: Further investigation of an ambivalent association". The Pakistan Development Review 28, (3): $175-193$.

Shaffer, P. 20I2. "Ten years of 'Q-Squared': Are two disciplines better than one?" Q-Squared Working Paper No. 57. Trent University.

Sheran, M. 2007. "The career and family choices of women: A dynamic analysis of labor force participation, schooling, marriage, and fertility decisions". Review of Economic Dynamics, 10: 367-399.

Solomon, B. and Kimmel, J. 2009. "Testing the inverseness of fertility and labor supply: The case of Ethiopia". IZA Discussion paper No. 3949. Western Michigan University and IZA.

Tadesse, F. and Headey, D. 20I0. "Urbanization and fertility rates in Ethiopia". Ethiopian Journal of Economics XIX, (2): 35-72.

Transitional Government of Ethiopia (1993). The National Population Policy of Ethiopia. Addis Ababa: Office of the Prime Minister.

UN Population Division (2005). Population challenges and development goals. Report No. ST/ESA/SER.A/248. Department of Economic and Social Affairs, New York.

UN Population Division (2017). World Population Prospects: Key findings and advance tables (The 2017 Revision). Report No. ESA/P/WP/248. Department of Economic and Social Affairs. New York.

UNDP (200I). UNDP Review of the poverty reduction strategy paper (PRSP). New York. http://www.lcgbangladesh.org/Povertylssues/repo rts/UNDP\%20PRSP\%20Assistance.pdf

UNFPA (2010). State of the World Population: Monitoring ICPD Goals.

in Ghana". Population Research and Policy Review 24, (I): 59-83.

Wooldridge JM (2009). Introductory Econometrics: A Modern Approach. Fourth 


\section{APPENDICES}

Appendix A

Parameter estimates for maternal work participation by the number of children and control variables

\begin{tabular}{|c|c|c|c|c|c|c|c|c|c|c|c|c|}
\hline \multirow[t]{3}{*}{ Variables } & \multicolumn{6}{|c|}{ Exogenous probit } & \multicolumn{6}{|c|}{ Ivprobit } \\
\hline & \multicolumn{2}{|c|}{ Full sample } & \multicolumn{2}{|c|}{ Urban sub-sample } & \multicolumn{2}{|c|}{ Rural sub-sample } & \multicolumn{2}{|c|}{ Full sample } & \multicolumn{2}{|c|}{ Urban sub-sample } & \multicolumn{2}{|c|}{ Rural sub-sample } \\
\hline & Coef. & $p>z$ & Coef. & $p>z$ & Coef. & $p>z$ & Coef. & $p>z$ & Coef. & $p>z$ & Coef. & $p>z$ \\
\hline Number of children & $\begin{array}{l}0918 \\
(.0321)\end{array}$ & 0.070 & $\begin{array}{l}-.2156 \\
(.0452)\end{array}$ & 0.061 & $\begin{array}{l}.1568 \\
(.0425)\end{array}$ & 0.004 & $\begin{array}{l}.1671 \\
(.2031)\end{array}$ & 0.418 & $\begin{array}{l}.0304 \\
(.1549)\end{array}$ & 0.315 & $\begin{array}{l}.8412 \\
(.1456)\end{array}$ & 0.113 \\
\hline Average age of children & $\begin{array}{l}.0982 \\
(.0241)\end{array}$ & 0.113 & $\begin{array}{l}.0352 \\
(.0098)\end{array}$ & 0.421 & $\begin{array}{l}.0934 \\
(.0401)\end{array}$ & 0.101 & $\begin{array}{l}.0745 \\
(.0127)\end{array}$ & 0.211 & $\begin{array}{l}.0112 \\
(.0198)\end{array}$ & 0.107 & $\begin{array}{l}-.0785 \\
(.0345)\end{array}$ & 0.113 \\
\hline Sex of household head & $\begin{array}{l}.1845 \\
(.1987)\end{array}$ & 0.451 & $\begin{array}{l}.5145 \\
(.1845)\end{array}$ & 0.054 & $\begin{array}{l}.1305 \\
(.35 \mid 2)\end{array}$ & 0.625 & $\begin{array}{l}.1562 \\
(.2189)\end{array}$ & 0.408 & $\begin{array}{l}.3190 \\
(.3163)\end{array}$ & 0.301 & $\begin{array}{l}.1052 \\
(.4009)\end{array}$ & 0.651 \\
\hline Age of household head & $\begin{array}{l}-.0107 \\
(.0074)\end{array}$ & 0.201 & $\begin{array}{l}.0212 \\
(.0151)\end{array}$ & 0.213 & $\begin{array}{l}-.826 \\
(.0321)\end{array}$ & 0.071 & $\begin{array}{l}-.0564 \\
(.0170)\end{array}$ & 0.215 & $\begin{array}{l}-.1151 \\
(.0338)\end{array}$ & 0.412 & $\begin{array}{l}-.0777 \\
(.0307)\end{array}$ & 0.137 \\
\hline $\begin{array}{l}\text { Female spouse's age at first } \\
\text { marriage }\end{array}$ & $\begin{array}{l}.1342 \\
(.0361)\end{array}$ & 0.105 & $\begin{array}{l}.2221 \\
(.0212)\end{array}$ & 0.265 & $\begin{array}{l}.0997 \\
(.0121)\end{array}$ & 0.415 & $\begin{array}{l}.1121 \\
(.0415)\end{array}$ & 0.511 & $\begin{array}{l}.2241 \\
(.0501)\end{array}$ & 0.671 & $\begin{array}{l}.1057 \\
(.05 / 2)\end{array}$ & 0.253 \\
\hline $\begin{array}{l}\text { Female spouse's years of } \\
\text { schooling }\end{array}$ & $\begin{array}{l}.0095 \\
(.0555)\end{array}$ & 0.524 & $\begin{array}{l}.0886 \\
(.0346)\end{array}$ & 0.111 & $\begin{array}{l}-.0213 \\
(.0358)\end{array}$ & 0.671 & $\begin{array}{l}.0652 \\
(.0398)\end{array}$ & 0.214 & $\begin{array}{l}.0757 \\
(.0322)\end{array}$ & 0.201 & $\begin{array}{l}.0152 \\
(.0333)\end{array}$ & 0.221 \\
\hline $\begin{array}{l}\text { Contraceptive use } \quad(Y e s=1, \\
\text { Otherwise }=0)\end{array}$ & $\begin{array}{l}.1412 \\
(.1042)\end{array}$ & 0.346 & $\begin{array}{l}.414 \mid \\
(.2112)\end{array}$ & 0.208 & $\begin{array}{l}.1111 \\
(.5242)\end{array}$ & $0.74 I$ & $\begin{array}{l}.1127 \\
(.2020)\end{array}$ & $0.58 \mathrm{I}$ & $\begin{array}{l}.4025 \\
(.4240)\end{array}$ & 0.289 & $\begin{array}{l}.0120 \\
(.4151)\end{array}$ & 0.888 \\
\hline $\begin{array}{ll}\text { Loan receipt } & (Y e s=1 \text {, } \\
\text { Otherwise }=0) & \end{array}$ & $\begin{array}{l}.1919 \\
(.1701)\end{array}$ & 0.230 & $\begin{array}{l}.7194 \\
(.1939)\end{array}$ & 0.031 & $\begin{array}{l}.1145 \\
(.12 \mid 2)\end{array}$ & 0.366 & $\begin{array}{l}.2191 \\
(.0881)\end{array}$ & 0.444 & $\begin{array}{l}.4171 \\
(.2235)\end{array}$ & 0.111 & $\begin{array}{l}.1515 \\
(.2320)\end{array}$ & 0.424 \\
\hline $\begin{array}{l}\text { Birr value of household assets } \\
\text { (log transformed) }\end{array}$ & $\begin{array}{l}.0215 \\
(.318)\end{array}$ & 0.352 & $\begin{array}{l}.10423 \\
(.0845)\end{array}$ & 0.086 & $\begin{array}{l}-.2104 \\
(.0398)\end{array}$ & 0.097 & $\begin{array}{l}.0197 \\
(.052)\end{array}$ & 0.412 & $\begin{array}{l}.1124 \\
(.0352)\end{array}$ & 0.075 & $\begin{array}{l}-.0982 \\
(.0804)\end{array}$ & 0.381 \\
\hline $\begin{array}{l}\text { Members other than parents } \\
\text { engaged in non-productive work }\end{array}$ & $\begin{array}{l}.3323 \\
(.1545)\end{array}$ & 0.012 & $\begin{array}{l}.6652 \\
(.2145)\end{array}$ & 0.051 & $\begin{array}{l}.2002 \\
(.2525)\end{array}$ & 0.216 & $\begin{array}{l}.4097 \\
(.1818)\end{array}$ & 0.143 & $\begin{array}{l}.6076 \\
(.304 I)\end{array}$ & 0.068 & $\begin{array}{l}.245 I \\
(.404 I)\end{array}$ & 0.019 \\
\hline $\begin{array}{l}\text { Members other than parents } \\
\text { engaged in productive work }\end{array}$ & $\begin{array}{l}-.0989 \\
(.1801)\end{array}$ & 0.601 & $\begin{array}{l}.4909 \\
(.2554)\end{array}$ & 0.134 & $\begin{array}{l}-.5021 \\
(.2444)\end{array}$ & 0.129 & $\begin{array}{l}-.0666 \\
(.1965)\end{array}$ & 0.184 & $\begin{array}{l}.4098 \\
(.2828)\end{array}$ & 0.113 & $\begin{array}{l}-.5142 \\
(.2099)\end{array}$ & 0.101 \\
\hline $\begin{array}{l}\text { Mean hours of work by } \\
\text { household members (excluding } \\
\text { parents) }\end{array}$ & $\begin{array}{l}-.1452 \\
(.1745)\end{array}$ & 0.521 & $\begin{array}{l}.354 \mid \\
(.25 \mid 3)\end{array}$ & 0.125 & $\begin{array}{l}-.0819 \\
(.2242)\end{array}$ & 0.210 & $\begin{array}{l}-.2535 \\
(.2004)\end{array}$ & $0.24 I$ & $\begin{array}{l}.2514 \\
(.2156)\end{array}$ & 0.121 & $\begin{array}{l}-.6852 \\
(.2002)\end{array}$ & 0.127 \\
\hline Constant & $\begin{array}{l}.0194 \\
(.2524)\end{array}$ & 0.699 & $\begin{array}{l}-.6523 \\
(.5124)\end{array}$ & 0.214 & $\begin{array}{l}.5262 \\
(.1426)\end{array}$ & 0.115 & $\begin{array}{l}.0098 \\
(.4251)\end{array}$ & 0.721 & $\begin{array}{l}-.8898 \\
(.9859) \\
\end{array}$ & 0.235 & $\begin{array}{l}.1104 \\
(9445)\end{array}$ & 0.546 \\
\hline
\end{tabular}

Standard errors are reported in parentheses. 


\section{Appendix B}

The present study uses two-step instrumental variable probit (ivprobit hereafter) method, which is one of the most common instrumental variable estimators (Wooldridge, 2009). In this procedure, the first step equation uses ordinary least squares to predict the number of children as a function of the sex mix of the two first-born siblings, controlling for other covariates.

The instrumental variable used consists of sex composition of the first two siblings born to a mother (same sex = I; otherwise, 0 ).

First, the structural form for the probit regression model $\left(\mathrm{Y}_{\mathrm{Ii}_{\mathrm{i}}}\right)$ can be given as:

$$
Y_{1 i}=\alpha_{0}+x_{1 i} \alpha_{1}+Y_{2 i} \beta+U_{i}
$$

where, $Y_{1 i}$ is the probability of mother's work participation for the $i^{\text {th }}$ household ( $I=$ If she works, $0=$ Otherwise)

$\alpha_{1}$ is parameter coefficient of the vector of an exogenous variable, $x_{1 i}$

$\beta$ is parameter coefficient of the vector of the number of children, $Y_{2 i}$

$U_{i}$ is an error term assumed to be normally distributed with mean zero.

However, the literature tells us that the number of children $\left(Y_{2 i}\right)$ is endogenous. That is,

$$
\operatorname{Cov}\left(Y_{2 i}, U_{i}\right) \neq 0
$$

If the equation is estimated by OLS, the estimate will be biased. Therefore, $Y_{2 i}$ should be itself predicted first in a reduced form as a function of sibling sex composition, $\mathrm{Z}_{\mathrm{i}}$, and other covariates.

$$
Y_{3 i}=\delta_{0}+x_{2 i} \delta_{2}+Z_{i} \gamma+e_{i}
$$

where, $Y_{3 i}$ is the predicted number of children for the $i^{\text {th }}$ household,

$\delta_{2}$ is parameter coefficient of the vector of exogenous variables, $x_{2 i}$, for the $\mathrm{i}^{\text {th }}$ household,

$\gamma$ is parameter coefficient of the vector of the instrumental variable, $Z_{i}$,

$e_{i}$ is an error term associated to household $\mathrm{i}$.

The instrumental variable, $Z_{i}$, is assumed to be uncorrelated with the error term, but partially correlated with the number of children. That is,

$$
\operatorname{Cov}\left(Z_{i}, U_{i}\right)=0
$$

and,

$$
\operatorname{Cov}\left(Z_{i}, Y_{2 i}\right) \neq 0 \text {. }
$$

The instrument is also assumed to be uncorrelated with other exogenous covariates. That is,

$$
\operatorname{Cov}\left(Z_{i}, X_{1 i}\right)=0 \text {. }
$$

Because $U_{i}$ is unobservable, $\operatorname{Cov}\left(Z_{i}, U_{i}\right)$ is untestable, unlike $\operatorname{Cov}\left(Z_{i}, Y_{2 i}\right)$ which can be readily tested using the data.

Once the number of children is exogenously predicted in (3), the final equation which estimates the mother's work participation can be specified by inserting the predicted number of children, $Y_{3 i}$, in place of $Y_{2 i}$ as:

$$
Y_{1 i}=\alpha_{0}+x_{3 i} \alpha_{3}+Y_{3 i} \beta+\varepsilon_{i}
$$

where, $Y_{1 i}$ is defined as in (I) above.

$\alpha_{3}$ is parameter coefficient of the vector of exogenous variables, $x_{3 i}$

$\beta$ is parameter coefficient of the estimated number of children, $Y_{3 i}$

$\varepsilon_{i}$ is an error term associated to household $\mathrm{i}$.

The estimated maternal work participation, $Y_{1 i}$, is now assumed to be unbiased. 